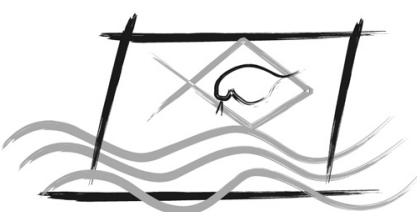

J. Braz. Soc. Ecotoxicol., v. 7, n. 2, 2012, 57-66

doi: $10.5132 / j b s e .2012 .02 .009$

ECOTOX - BRASIL

\title{
Key Issues in Aquatic Ecotoxicology in Brazil: A Critical Review
}

\author{
M. Krull \& F. Barros \\ Laboratório de Ecologia Bentônica, Zoology Department, Federal University of Bahia - UFBA, Institute of Biology, \\ Postcode 40170-115, Salvador BA, Brazil
}

(Received May 11, 2010; Accept December 31, 2010)

\begin{abstract}
Several studies have been questioning and encouraging paradigms shift in ecotoxicology so it can better integrate ecological aspects. In tropical countries, like Brazil, it is still a developing issue. The present study aimed to evaluate the use of Aquatic Ecotoxicology in Brazil based on the following key issues: the criteria for test organism selection; the most used species, routes, types of exposures and endpoints, and; the importance given to multispecies and in situ tests. A total of 227 publications authored by Brazilian researchers were analyzed and it was observed that among the reasons for test organism selection, its origin (native species) was the most used. However, $48 \%$ of the reviewed studies did not report the reasons for species selection. Among the most used species are respectively: Daphnia magna, Daphnia similis, and Danio rerio. In situ assays, as well as multispecies test, represented less than 5\% of all publications. Acute laboratory toxicity tests, using water as route of exposure evaluating mortality as endpoint were the most frequent tests. The present work identified that (i) the majority of assays used standardized tests with exotic species; (ii) few in situ methods were developed; (iii) few studies used sediment as route of exposure, and (iv) few methods were developed at higher levels of biological organization. Thus, the results of this work suggest that there is a need for more ecologically relevant tests, such as multispecies and in situ tests in Brazil.
\end{abstract}

Key Words: Aquatic Ecotoxicology, Critical Review, Key Issues, Paradigms, Tropical Countries, Brazil.

\section{Questões-chave na Ecotoxicologia Aquática no Brasil: Uma Revisão Crítica}

\section{Resumo}

Diversos trabalhos vêm questionando e incentivando mudanças nos paradigmas na ecotoxicologia, para que essa possa melhor integrar aspectos ecológicos. Em paises tropicais como o Brasil, esta ainda é uma questão em desenvolvimento. O presente estudo teve como objetivo avaliar o uso da Ecotoxicologia Aquática no Brasil baseado nas seguintes questões chaves: o critério utilizado para a escolha do organismo teste; as espécies, rotas, tipos de exposição, e endpoints mais utilizados, e; a importância dada a testes in situ e testes com mais de uma espécie. Um total de 227 publicações de autoria de pesquisadores brasileiros foi analisado e observou-se que entre os motivos para a escolha do organismo teste, a sua origem (espécie nativa) foi o mais utilizado. No entanto, $48 \%$ dos trabalhos revisados não apontaram os motivos para a escolha da espécie. Entre as espécies mais freqüentes, estão respectivamente: Daphnia magna, Daphnia similis, e Danio rerio. Ensaios in situ, assim como testes com mais de uma espécie, representaram menos de 5\% das publicações. Ensaios agudos realizados em laboratório, utilizando água como rota de exposição e mortalidade como endpoint foram os testes mais freqüentes. O presente estudo identificou que (i) a maioria dos ensaios utilizou testes padronizados com espécies exóticas; (ii) poucos métodos foram desenvolvidos in situ; (iii) poucos trabalhos utilizaram sedimento como rota de exposição, e (iv) poucos métodos foram desenvolvidos em níveis superiores de organização biológica. Neste sentido, os resultados deste trabalho apontam para a necessidade de testes ecologicamente mais relevantes no Brasil, como testes in situ e com mais de uma espécie.

Palavras-chave: Ecotoxicologia Aquática, Revisão Crítica, Questões-chave, Paradigmas, Paises Tropicais, Brasil. 


\section{INTRODUCTION}

Ecotoxicology is a science that integrates approaches of ecology and toxicology in order to evaluate and predict the effects of contaminants in biological systems, and Aquatic Ecotoxicology is a branch of science that studies those effects in aquatic ecosystems (Moiseenko, 2008). Contaminants can affect organisms in different levels of biological organization, i.e. biochemical, physiological, individual, population, communities and ecosystems (Newman \& Clements, 2008). Although the ultimate level of concern may be in higher levels of biological organization (Maltby, 1999), nowadays the field of ecotoxicology still seems to go in opposite direction with emphasis on individual effects and physiologic case studies (Emlen \& Springman, 2007).

Althought the field of ecotoxicology has progressed substantially (Cairns, 2005), several studies have been questioning and encouraging paradigms (sensu Kuhn, 1970) shift in ecotoxicology so it can better integrate ecological aspects (e.g. Cairns, 1992; Chapman; 1998; Chapman, 2002; Relyea \& Hoverman, 2006; Baird et al., 2007). This discussion have been addressing key issues such as the relevance of the species, routes of exposure and test selection (Chapman, 1995a; Chapman, 2002), the limitations of single species tests and the importance of more ecological relevant tests (Cairns, 1984; Clements \& Kiffney, 1994; Clements, 2000), and; the extrapolation of responses at lower levels of biological organization to higher levels (Calow, 1994; Chapman, 1995a). However, ecotoxicology is still more involved with toxicology than with ecology (Calow \& Forbes, 2003). Thus, the development of integrated approaches of those two sciences is still a challenging task (Schmitt-Jansen et al., 2008).

The challenges in the field of ecotoxicology are even greater in tropical countries, since most of these countries are developing nations, with relatively scarce financial resources and lack of infrastructure for advanced pollution control (Kwok et al., 2007). Furthermore, despite having substantially higher biodiversity, it is well know that tropic ecosystems are less studied than temperate ecosystems (Lacher \& Goldstein, 1997). Among tropical countries, Brazil stands with the larger territory, covering eight million $\mathrm{km}^{2}$, and jurisdiction over 3,5 million $\mathrm{km}^{2}$ of coastal waters, beside having the largest river system in the world (Brandon et al., 2005). In Brazil, ecotoxicology is still underexplored, but it is a developing area (Magalhães \& Ferrão-Filho, 2008).

Given the importance to paradigms shift in ecotoxicology, its development in scientific community and its urgency in tropical countries, this review aims to evaluate the use of ecotoxicology in Brazil, based on the following questions: (i) what are the main reasons for organism test selection in Brazil?; (ii) what are the most used species in Brazil?; (iii) what importance is given to multispecies and in situ assays?; (iv) which is the most used route of exposure?; (v) which is the most used endpoint?; (vi) which is the most used type of exposure?; and (vii) what are the main objectives of ecotoxicological studies in Brazil?

\section{MATERIAL AND METHODS}

The bibliographic survey has been conducted from august to october of 2009 through the research platforms Web of Knowledge, Science Direct and SCIELO, and through the specific journals Environmental Toxicology and Chemistry and Journal of the Brazilian Society of Ecotoxicology databases. The key words used on the cross-search were: Acute, Bay, Bioassay, Benthic, Brazil, Contamination, Chronic, Ecological risk assessment, Environmental risk assessment, Ecotoxicological, Ecotoxicology, Estuarine, Estuary, Marine, Microcosms, Mesocosms, Sediment, Toxicity, Test, Water, Pollution, Endpoint, Effects and Pore water. Only papers published between 1980 and 2009 were selected.

The criteria for nationality of the papers were based on first author's affiliations, or most of the author's affiliations. The questions raised in this study had focus on the use of bioassay, thus, studies that had collect organisms in the field for biomarkers or bioaccumulation evaluation were not included.

Afterwards, all the papers were analyzed and a table was filed with all the information required to answers the questions. The first author affiliation was considered to evaluate where the study was made. Regarding the type of exposure of the test, the papers were classified as acute, subchronic, chronic, or combined exposure (e.g. acute and chronic). Thus, if one study, for example, has done four acute and two chronic assays, it has been classified as acute and chronic test. Studies that have informed the criteria for species selection based on characteristics of large taxonomical groups (e.g. fish) or life stages (e.g. larval) were here considered too general and were not accounted. However, only studies that informed the criteria based on characteristics of genus or species were considered.

Regarding endpoints, multiple enzyme activities were considered as one endpoint (i.e. enzymatic activity), as well as hematological parameters; metabolic parameters (e.g. glycogen, metallothionein); histopathological lesions (e.g. liver, kidney and gill); genotoxicity (e.g. DNA damage and micronucleus); and growth (e.g. height and weight). Mortality and survivor were considered the same endpoint, where the different approaches $\left(\mathrm{LC}_{50}, \mathrm{LT}_{50}, \mathrm{NOEC}\right)$ were counted. As some authors defined mortality and immobilization as the same endpoint for cladocerans, it was standardized as mortality. All endpoints were considered regard to the number of species used. Thus, if a study used two species and mortality $\left(\mathrm{LC}_{50}\right)$ as endpoint it was counted as two endpoints. The evaluation of responses across different levels of biological organization was based on model proposed by Clements \& Newman (2002).

The following categories were considered based on the objectives of the papers: (1) Species test, studies which aimed to evaluate the use of one or more species, or different life stages, in ecotoxicological tests; (2) Substance test, those studies that evaluated the sensitivity of organisms to one or more substances (e.g. pesticides, herbicides, metals) and/or synergetic effects between these; (3) Effluent test, studies that evaluated the toxicity of an effluent or the efficiency of a treatment process; (4) Endpoint test, evaluated the use of a 
specific endpoint or biomarker in an organism previously used in ecotoxicological tests; (5) Environmental assessment tests, evaluated the degree of pollution or degradation of a given area; (6) Methodological test, aimed to test hypotheses about the suitability of a test; and (7) Review. Categories are not mutually exclusive, so depending on paper's purpose, it can be included in more than one category. Camargo \& Martinez (2006), for example, investigated the suitability of an in situ test with Prochilodus lineatus (Methodological test) and evaluated from a set of biomarkers which could work as a sensitive tool (Endpoint test) for the assessment of environmental quality of Cambé stream (Environmental assessment test).

\section{RESULTS}

A total of 227 publications were analyzed between years 1981 and 2009, where nine of these works were reviews. All references and list of species described in the present work can be made available if requested. The southeast and south of Brazil had the majority of publications, about 85\%, with 109 and 85 papers, respectively. Among states, São Paulo stood out with $39.9 \%$ of all publications.

Among ecotoxicological tests, $95.5 \%$ were performed in the laboratory, $2.7 \%$ in situ, and $1.8 \%$ were performed both in situ and in laboratory. Of these tests, $55.9 \%$ were acute, $21 \%$ chronic, $3.6 \%$ subchronic and $19.5 \%$ integrated tests (i.e. $16.3 \%+2.7 \%+0.5 \%$ ) (Fig. 1A). Regarding the number of species, $97.3 \%(71.8 \%+16.9 \%+4.5 \%+4.1 \%)$ of the studies used singlespecies tests, among which, $25.5 \%$ of these tests used more than one species, but in separate assays (Fig. 1B). Only $2.7 \%$ represented multispecies tests (e.g. microcosms and manipulative in situ tests).

In this study, $83.4 \%$ of the analyzed studies used water as route of exposure, $6.9 \%$ used whole sediment, $2.3 \%$ used extracts of the sediment (i.e. porewater or elutriate) and 7.3\% used more than one route (Fig. 1C).

Regarding the species, $74.5 \%$ used freshwater species, $7.3 \%$ estuarine species, 9.1\% estuarine/marine species and 9.1\% marine species. Fishes were the most used group of organisms (29.2\%) followed by cladocerans $(22.1 \%)$ and bacteria (8.3\%) (Fig. 2A). However, from the four most used species, three were cladocerans (Fig. 2B). The species Rhamdia quelen and Tiburonella viscana were used in nine papers each, being tied in ninth in the ranking of the most used species. The species Crassostrea rhizophorae, Lytechinus variegatus, and Vibrio fischeri were used in eight papers each.

In the present work, $48 \%$ of all publications did not inform the species selection criteria. Among the used reasons for species selection, the argument about its origin (native species) was the most used (21.8\%) followed by laboratorial issues $(15.3 \%)$ such as collection, maintenance, and cost of the test (Fig. 3A). Although "native species" was the main mentioned criteria, $47.4 \%$ of the studies did not report whether the species is native or not.

Regarding the endpoints, mortality was the most used (31.3\%), followed by enzymatic activity (12.3\%) (Fig. 3B).
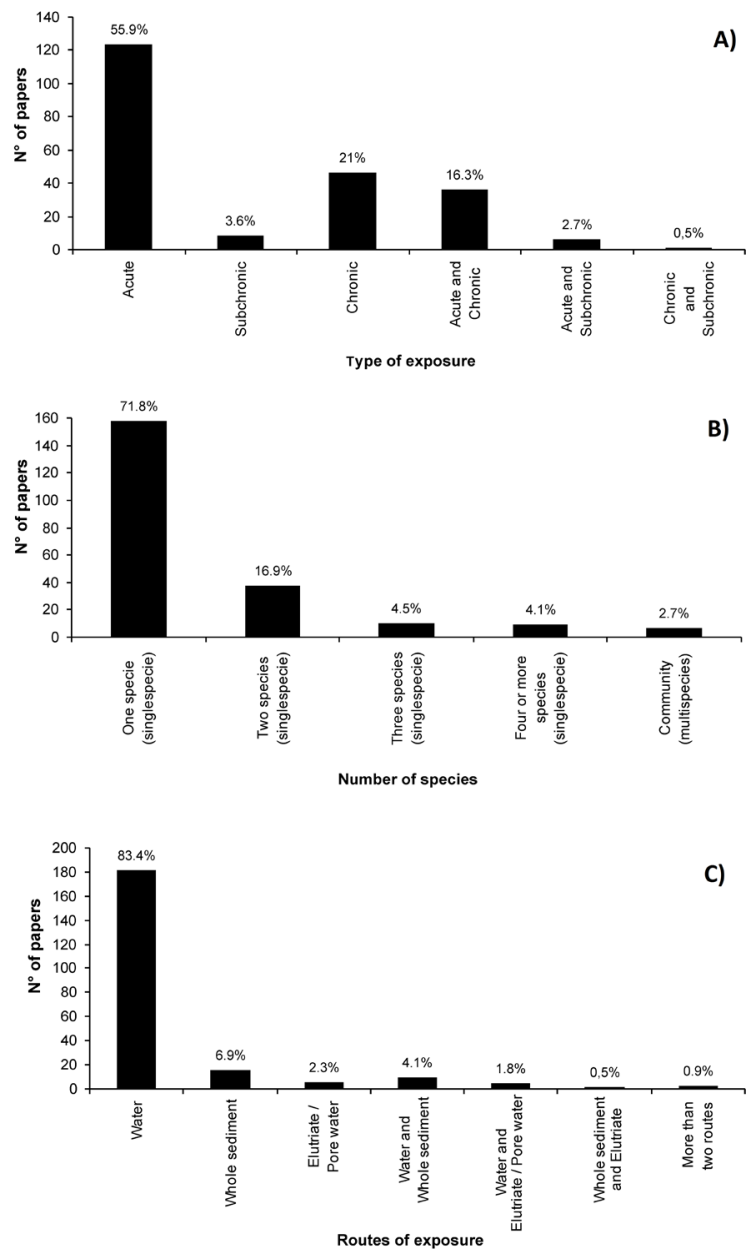

Figure 1 - Number of papers published based on (A) type of exposure, (B) used number of species and $(C)$ routes of exposure.
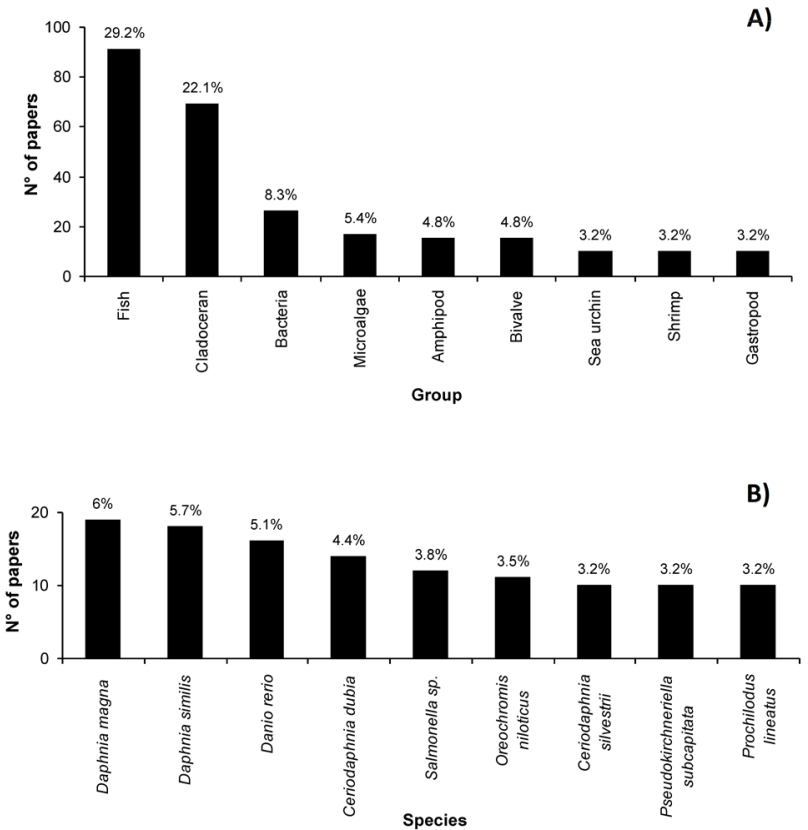

Figure 2 - Number of papers published with the most frequent (A) major taxonomic groups and (B) species. 
As for mortality, $\mathrm{LC}_{50}$ (i.e. contaminant lethal concentration for $50 \%$ of test organisms in a given time) was the most used approach representing 94 assays.
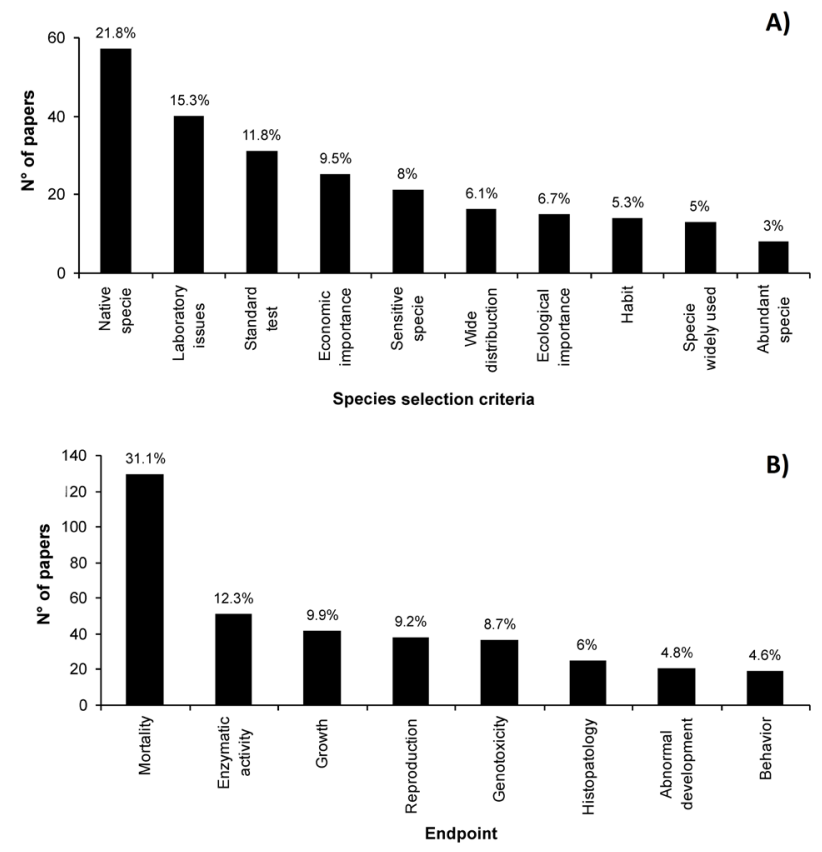

Figure 3 - Number of papers published based on (A) species selection criteria and (B) endpoints.

Responses at organism level of biological organization were the most used with $43.5 \%$ (Fig. 4A). Studies that presented integrated responses between more than one level of biological organization, e.g. biochemical/physiological and organism, represented $23 \%$.

Among the categories based on the focus and objective of the work, substance tests was the most common $(38.9 \%)$, followed by environmental assessment $(25.2 \%)$ and effluent tests $(10.3 \%)$ (Fig. 4B). Among the tested substances, metals were the most tested with a total of 31 studies, followed by pesticides (19 studies) and herbicides (16 studies).

\section{DISCUSSION}

\section{What are the main reasons for organism test selection in Brazil?}

Many authors suggests that test organism selection is primary related to laboratory issues, such as culturing facilities and cost of testing (e.g. Pontasch et al., 1989; Chapman, 1995a), although there seems to be a consensus that for greater ecological relevance the species should be native; sensitive to the contaminant; be important in the food chain and/or be keystone species in the ecosystem (e.g. Chapman, 2002; Baird et al., 2007). According to Chapman (2002), this is one of the key issues that differentiate
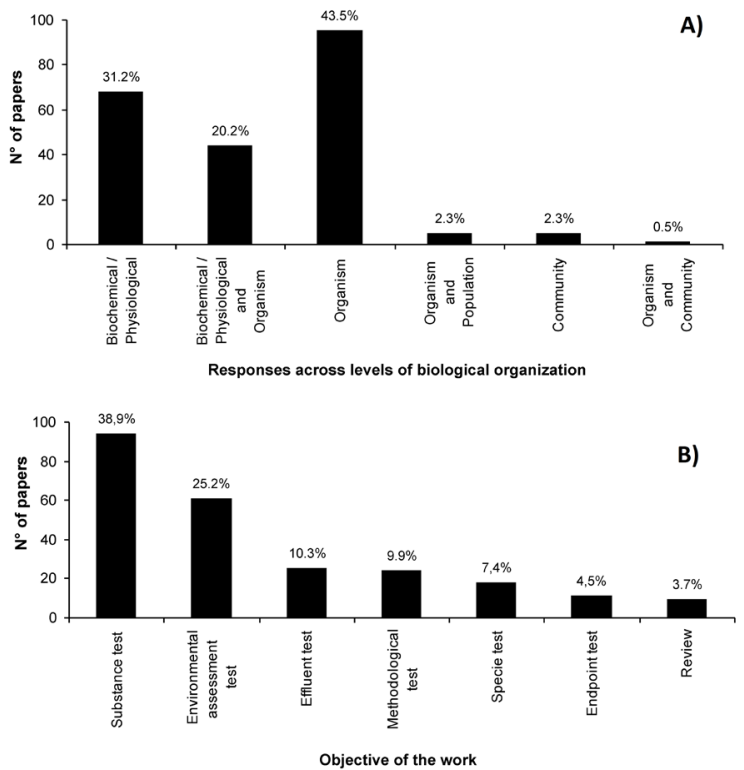

Figure 4 - Number of papers published based on (A) responses across different levels of biological organization and (B) objectives of the work.

ecotoxicology of a more simplistic approach, which can be defined as environmental toxicology.

The present work results highlighted the low importance given to the reasons for species selection, in which only $52 \%$ of all publications made their reasons clear. This information should be present and clear in the paper, not only for the reader but especially for the author. The researcher should keep in focus what are the questions and the purposes of the work, as well as the limitations of the test, so the organism selection can allow a better understanding and interpretation of the results (Connel et al, 1999). In the case of a test which has the goal of evaluate the impacts of some contaminant present in sediment in the benthic community or assess the ecological risk of a pesticide in a fish of great economic value, certainly, the reasons that lead to species selection should be different. Thus, the choice of the test organism has great influence on the relevance, success, and interpretation of the test (Macdonald \& Ingersoll, 2003).

"Native species" was the most used criteria for species selection. However, $48 \%$ of all publications did not mention the reasons for species selection, thus it can have hidden the real reasons that lead the Brazilian researcher to species selection. Factors such as cost and laboratory conditions seem to be more involved in such choice. An indication of this is that more than half of all works has not indicated whether the species is native or not, and four between five of the most used species are exotic (Fig. 4B).

Notably, low concern has been given to the chosen species sensitivity (Fig. 3A). Different species at the same environment can show different sensibility to specific toxic substances, so that while some species may have effects over survivor, others may have no observed effects (Fleeger et al., 2003). Consequently, 
depending on the species, if it is not sufficiently sensible to the contaminant, it can lead to false results about the bioavailability of the contaminant, i.e. not measure the real effect of toxicity in the environment (McPherson \& Chapman, 2000).

It is important to recognize that there is a trade-off between these reasons that enhance or not the relevance of the test (Breitholtz et al., 2006). Therefore, we must have in mind what we want to protect and what need to be tested in ecotoxicological tests (Calow, 1998).

\section{What are the most used species in ecotoxicological tests in Brazil?}

There are significant advantages in the use of species which have standards methods developed, as simplified logistics, high replicability of data, and important features for regulatory goals (Landis \& Yu, 2003). Ecotoxicological tests that are used for regulatory and legal control of substances such as pesticides for example, might show the same results in different laboratories and at different times (Soares \& Calow, 1993). However, the number of standard tests in Brazil is limited, and few species used in these tests are native (Dutra et al., 2008).

Although the reason "species used in standard tests" has not been the most used, seven of the nine most used species have their standards tests developed (ABNT, 2004; ABNT, 2005a; ABNT, 2005b; ISO, 2005; ABNT, 2009). In addiction, the four most commonly used species are exotic. These results are even more important when considered with the main goals of the works here reviewed. Due to shortage of data on the sensitivity of Brazilian species these works should focus mostly on native species, or to establish the difference in sensitivity between species, since native tropical species may have different sensibility when compared with exotic species (Lopes et al., 2007; Kwok et al., 2007).

In this sense, in environmental assessment studies, if the goal is more than an initial screening, native species should be used (Chapman, 2002). Furthermore, the use of standardized tests must also have an appropriate experimental design. Freshwater organisms, for example, should not be exposed to brackish conditions, as these species are not adapted to this condition (e.g. Lattuada et al., 2009).

Some results found on the present study were similar to the European Centre of Ecotoxicology and Toxicology of Chemicals database (ECETOC, 2003), which evaluated the data of 5,460 studies on substance's toxicity between years 1970 and 2000 . In this database $76 \%$ of the species were freshwater species. Moreover, fishes were also the most used group with over $50 \%$, while daphnids were used in just over $10 \%$. Comparing the results, it is evident that there is a tendency of ecotoxicology worldwide and not only just a limitation in Brazil.

\section{What importance is given to multispecies and in situ assays?}

Laboratorial singlespecies tests are relatively fast, easy and inexpensive to be conduct, and have protocols that facilitate validation and interpretation of test results (Calow \& Forbes, 2003). However, some authors argue that (i) laboratory singlespecies tests have low ecological relevance (e.g. Clements, 2000); (ii) these tests are not the most accurate to predict responses at higher levels of biological organization, since they do not consider interspecific interactions such as predation and competition (Clements \& Newman, 2002), and (iii) are usually conducted with exotic species and exposed to physicochemical conditions that lack similarity with natural world (Pontasch et al., 1989). In this sense, more accurate tests are needed to avoid the cost of false negative (overprotective) or false positive results (underprotective) (Pontasch \& Cairns, 1991).

Important recent developments in ecotoxicology such as the use of microcosms, mesocosms and in situ experiments have improved the ability to predict the effects of contaminants at higher levels of biological organization (Clements \& Kiffney, 1994). However, in the present study, it was observed a limited number of in situ and multispecies approaches.

Concerning multispecies tests, two studies focused on testing bacterial community using different approaches. Crapez et al. (2000) evaluated the effects of benzoic acid, toluene, benzene, and xylene on the biomass of bacterial community through protein dosage. Oliveira et al. (2007) evaluated the treatment efficiency of an industrial effluent through the assessment of organic matter reduction, using a respirometry test with the bacterial community.

Regarding multispecies assays, only one publication utilized microcosm, despite there are several methods described in the literature (e.g. Austen \& Somerfield, 1997; Clément et al., 2004). Resgalla et al. (2007) used both laboratory and in situ microcosms tests to evaluate the effects of an herbicide in the plankton communities. In the latter study they found that the phytoplankton community is more susceptible to the effects of the herbicide in both assays. Lopes et al. (2007) also used in situ microcosms to simulate the effect of a runoff event in an agricultural area after using a pesticide, however, using a single species assay with the tropical cladoceran Diaphanosoma brachyurum.

In situ works were not representative, although they have shown great potential. The utilization of cages and chambers were the most used approaches including different organisms, such as cladocerans (Lopes et al., 2007), shrimps (Lüchmann et al., 2007), insects (Dornfeld et al., 2006) and fishes (Araújo et al., 2006; Camargo \& Martinez; 2006; Becker et al., 2009). For instance, Corrêa et al. (2009) used calcium alginate to immobilize the microalgae Pseudokirchneriella subcapitada, allowing the use of microalgae at in situ assays. Being relatively low cost methodologies, these can be easily used combined with laboratory tests.

Another used approach for in situ assays was the utilization of manipulative tests evaluating the succession of encrusting benthic community in polluted and unpolluted sites. This approach takes into account that colonization will differ between those sites reflecting on the community structure (i.e. richness, abundance and diversity) (Clements \& Newman, 
2002). Breves-Ramos et al. (2005) evaluated the succession of intertidal benthic community, where transects were scraped and then monitored. Another methodology was the transplant of wooden boards colonized in polluted and unpolluted sites (Mayer-Pinto \& Junqueira, 2003). These tests can provide important information about the effects of pollutants in community's structure, therefore, in situ manipulative tests must be well designed to reduce the effects of confounding variables that may affect the results and interpretation of the test, such as temperature, salinity, dissolved oxygen and seasonality (Liber et al., 2007). Colonization assays may also use sediment as substrate (e.g. Watzin et al., 1994; Roach et al, 2001), what can increase the test relevance, since most of the contaminants usually accumulate in the sediment (Chapman et al., 1999).

\section{Which is the most used route of exposure?}

There are three major routes that contaminants can entry into organism: dermal exposure, ingestion and inhalation (Clements \& Newman, 2008). These routes can be linked directly to where an organisms lives and how it lives (Chapman, 1995a). Benthic organisms burrowing and feeding behavior, for example, varies greatly, so importance of dissolved and particulate metal exposure routes also varies (Simpson \& Batley, 2007). The ingestion of contaminated sediment, for example, is an important route and often the dominant uptake pathway for deposit-feeding invertebrates (Forbes et al., 1998) and benthic fishes (Newman \& Clements, 2008). However, sediment-water interface provides a more realistic exposure to epibenthic organisms (Maranhão et al., 2009). Thus, the choice of the test organism must be linked directly to the route of exposure (Chapman, 1995a).

Carvalho et al., (2006) by exposing two species of fishes, Oreochromis niloticus and Danio rerio, to mercury contaminated sediments in laboratory observed that only the first species bioaccumulated mercury and that was related to the fish behavior of stirring up the sediment and increasing the possibility of absorption of mercury. Researchers also must be aware of possible routes that could difficult the interpretation of the results. Studies in situ, for example, expose test organisms to natural conditions. According to this, test organisms exposed in cages might be exposed to more than one route of exposure, e.g. water and sediment, what may difficult the interpretation about the quality of just one of these routes (e.g. Camargo \& Martinez, 2006).

Initially, ecotoxicological tests utilized water as the main route of exposure (McLusky \& Elliot, 2004), therefore, it is known that water is not the main route for all organisms and substances. It is well recognized that sediment can serve both as sink and source of contaminants (Chapman et al., 1999), causing effects over the whole ecosystem, including pelagic organisms that lives on the water column (Clément et al., 2004). Besides, sediments also provide habitat, feeding and rearing areas for aquatic biota (Chapman, 1989; Baudo et al., 1999). Even thought, in the present work water was still the most used route of exposure with more than $80 \%$ of the total. This result may be linked to the fact that most of the studies assessed the species sensitivity to substances added to water in laboratory.

\section{Which is the most used endpoint?}

Endpoints can be included in two broad categories: assessment and measured endpoints. Assessment endpoints can be defined as an explicit expression of the environmental to be protected, operationally defined by an ecological entity and some attributes (e.g. a community, such as benthic community or an ecosystem, like an estuary) (USEPA, 1998). Assessment endpoints may not be always measured directly, thought. In this sense, certain components of the ecosystem are measured (i.e. measured endpoints) to provide reasonable indications of the whole (Chapman, 1998).

Choosing the appropriated endpoint is of extremely importance for the ecological relevance of the test (Burton et al., 2002). Like species, measured endpoints should not be chosen simply because there are protocols already available (Norton et al., 2002), but based on how well they represent the assessment endpoint (Landis et al., 1994). However, the link between measured and assessment endpoint is often unclear (Chapman, 2008).

Responses to pollution can occur at different levels of biological organization such as cellular, organism, population and community, thus the effects of pollution can also be measured at these different levels (Newman \& Clements, 2008). In this study it was found that there is an emphasis on responses at lower levels of biological organization (Fig. 4A). Responses at biochemical and physiological levels are recognized as more replicable (Lam \& Gray, 2001), can act as an early warning and provide information about how toxicity affect organisms (Clements \& Newman, 2002). However, responses at these levels are often part of homeostatic responses that by definition, do not translate into population and community responses. Therefore, these responses may not be useful when considered as synonyms or when replaced by primary effects (Chapman, 1995b).

There is no better or correct level of biological organization to study the effects of pollution (Maltby, 1999). So, what should not be done is to measure properties at any level of biological organization without any good ecological reason (Calow, 1994). A sensible strategy would be to use responses at different levels, e.g. physiological, organism and community, since this measures serve different proposes (Underwood \& Peterson, 1988; Maltby, 1999; Clements \& Newman, 2002). However, so far there were few Brazilian studies that used integrated responses and these studies were at lower levels of biological organization (Fig. 4A).

\section{Which is the most used type of exposure?}

The results regarding the duration of the test are similar to those reported by ECETOC (2003), where 67\% were acute 
tests, $13 \%$ subchronic and $20 \%$ chronic. Therefore, it can be inferred that it does not happen only in Brazil and perhaps may be a tendency in ecotoxicology around the world.

Most Brazilian studies had focused on acute effects, regardless the fact that contamination in aquatic ecosystem by metal and pesticides (most tested and related substances to environmental degradation in these studies) assumes the character of chronic and not acute pollution (Rodgher et al., 2008; Relyea, 2009). Although acute bioassays provide useful information, they may not be representative of typical environmental exposure, i.e. low concentrations over extended periods (Emery et al., 1997). Thus, chronic tests involving longer periods of exposure may have greater similarity with the environmental and greater ecological relevance than acute tests of short duration (McGee et al., 2004).

\section{What are the main objectives of ecotoxicological studies in Brazil?}

Evaluate the sensitivity of species to substances such as metals, pesticides, and herbicides was the main goal of ecotoxicological studies in Brazil. However, it is important to notice that it is nearly impossible to test all emerging substances (Chapman, 2006) or the sensitivity of all organisms (Cairns, 1992), besides, communities of organisms in nature are exposed to a mixture of contaminants (Relyea, 2009). In addition, the same substance may also be tested by the same organism, but using different endpoints (e.g. Glusczak et al., 2007; Kreutz et al., 2008). Thus, the fact that a substance has never been tested in determined species may not be a relevant reason for the execution of a work (Chapman \& Guerra, 2005). Researchers must evaluate ethically the relevance of costs, i.e. money and time, for conducting these studies.

For environmental assessment, it is important to notice the low number of works using integrated approaches and/or in situ assays. Integrated approaches are needed for better decisionmaking and also to the establishment of public policies (Cesar et al., 2009). Multivariate analysis allows the integration of data of different natures, such as chemical analysis, toxicological assays and in situ analysis (e.g. sediment quality triad; Chapman, 1986) allowing a deeper and more robust interpretation of data (Choueri et al., 2009). However, few ecotoxicological studies had used integrated approaches.

Integrate responses at different levels of biological organization is also essential for greater relevance of the test (Clements \& Newman, 2002). Besides, the utilization of native species, chronic tests and of sediment as route of exposure are needed to improve our capacity to predict the effects of pollutants in aquatic ecosystems. Works evaluating the difference in sensitivity between exotic and native species, and developing in situ and tests at higher levels of biological organization methodologies are crucial and should be developed.

Effluent assays represented about $10 \%$ of all publications, which mostly used standard tests. The rationale of using standard toxicological tests for regulatory goals is in enhancing reproducibility and replicability (Møller et al., 1994). CONAMA's resolution 357/05 article 34, paragraph 2 , establish that sewages discharge should be regulated based on standardized ecotoxicological tests. However, scientific studies should not be limited to standard tests using exotic species where differences in sensitivity must be established and new methodologies developed for the implementation of public policies.

Species to be tested should be chosen primarily based on ecological issues (Chapman, 1995a; Chapman, 2002). Ecological community studies can provide important information for the identification of ecological relationships and key species in the environment. Moreover, the results should not be limited to biomarkers and should also be established at populations and community levels.

\section{CONCLUSIONS}

In the present work, it was possible to note the lack of importance given to the organism test selection in Brazil, despite the choice of the organism test be a determining factor for the relevance of the test. Thus, if the test is more than an initial screening, the criteria for species selection should be based primarily on ecological issues, and must be present and clear on the text.

Not only in Brazil but possibly in most developing tropical countries, laboratory issues such as cost and maintenance of the test, seems to be determining factors for species and type of exposure selection. The consequences are that: (i) the majority of assays used standardized tests with exotic species; ii) few in situ methods were developed; (iii) few studies used sediment as route of exposure, and ((iv) few methods were developed at higher levels of biological organization, i.e. population and community. In this sense, the results of this work suggests that that there is a need for developing integrated approaches, such as sediment quality triad and tiered approach. Furthermore, it is urgent the developing of in situ and multispecies assays in Brazil.

Some of the results in this review are similar to the European Centre of Ecotoxicology and Toxicology of Chemical (2003) database, as most of the tests were acute, used freshwater species, and fishes as the main group of organisms. It shows that these results may be due to a worldwide trend in ecotoxicology and not just a limitation of Brazil. However, it doesn't mean that reevaluating this issue is not necessary. Chronic tests usually are more representative of the exposure find in the environmental, i.e. low concentrations for extended periods, and should also be performed in addition to acute assays.

In this sense, ecotoxicology in Brazil seems to be more involved with environmental toxicology than with ecotoxicology it self. Thus, the scientific community must be alert to paradigms shifts in the field of ecotoxicology so proper conservation and remediation studies can be implemented for the preservation of aquatic ecosystems. 


\section{ACKNOWLEDGMENTS}

We thank Salomão José Cohin de Pinho and Joana Fidelis da Paixão for their thoughtful reviews. F. Barros was supported by a fellowship PQ-CNPq (No. 302642/2008-0). We also thank two anonymous referees for the corrections and valuable comments on the manuscript.

\section{REFERENCES}

ABNT (ASSOCIAÇÃO BRASILEIRA DE NORMAS TÉCNICAS), 2004, NBR 15088: Ecotoxicologia aquática - Toxicidade aguda - Método de ensaio com peixes.

ABNT (ASSOCIAÇÃO BRASILEIRA DE NORMAS TÉCNICAS), 2005a, NBR 12648 - Ecotoxicologia aquática - Toxicidade crônica - Método de ensaio com algas (Chlorophyceae).

ABNT (ASSOCIAÇÃO BRASILEIRA DE NORMAS TÉCNICAS), 2005b, NBR 13373 - Ecotoxicologia aquática - Toxicidade crônica - Método de ensaio com Ceriodaphnia spp (Crustacea, Cladrocera).

ABNT (ASSOCIAÇÃO BRASILEIRA DE NORMAS TÉCNICAS), 2009, NBR 12713 - Ecotoxicologia aquática - Toxicidade aguda - Método de ensaio com Daphnia spp (Crustacea, Cladocera).

ALMEIDA, C.A. \& ROCHA, O., 2006, Estudo comparativo da qualidade dos sedimentos dos reservatórios do rio Tietê (SP). J. Braz. Soc. Ecotoxicol., 1:141-145. doi:10.5132/ jbse.2006.02.010

ARAÚJO, C. V. M., COHIN-DE-PINHO, S. J., SANTOS, J. S., DELGado, F., SANTANA, L. C. S., CHASTINET, C. B. A. \& da SILVA, E.M., 2006, In situ and laboratory bioassays using Poecilia reticulata Peters, 1859 in the biomonitoring of an acidic lake at Camaçari, BA, Brazil. Chemosphere., 65: 599-603. doi:10.1016/j.chemosphere.2006.02.006

AUSTEN, M. C. \& SOMERFIELD, P. J. A., 1997, Community level sediment bioassay applied to an estuarine heavy metal gradient. Mar. Environ. Res., 43: 315-328. doi:10.1016/S01411136(96)00094-3

BAIRD, D. J., BROWN, S. S., LAGADIC, L., LIESS, M., MALTBY, L., MOREIRA-SANTOS, M., SCHULZ, R. \& SCOTT, G. I., 2007, In situ-based effects measures: determining the ecological relevance of measured responses. Integr. Environ. Assess. Manag., 3: 259-267. doi:10.1897/IEAM_2006-031.1

BAUDO, R., BELTRAMI, M. \& ROSSI, D., 1999, In situ tests to assess the potential toxicity of aquatic sediments. Aquat. Ecosyst. Health Manage., 2: 361-365. doi:10.1016/S14634988(99)00013-5

BECKER, A. G., MORAES, B. S., MENEZES, C. C., LORO, V. L., SANTOS, D. R., REICHERT, J. M. \& BALDISSEROTO, B., 2009, Pesticide contamination of water alters the metabolism of juvenile silver catfish, Rhamdia quelen. Ecotoxicol. Environ. Saf., 72: 1734-1739. doi:10.1016/j.ecoenv.2009.01.006

BRANDON, K., FONSECA, G. A. B., RHYLANDS, A. \& SILVA, J. M. C., 2005, Conservação brasileira: desafios e oportunidades. Megadiversidade, 1: 7-13.

BREITHOLTZ,M.,RUDÉN,C.,HANSSONB,S.O.\&BENGTSSON, B., 2006, Ten challenges for improved ecotoxicological testing in environmental risk assessment. Ecotox. Environ. Safe., 63: 324-335. doi:10.1016/j.ecoenv.2005.12.009

BREVES-RAMOS, A., LAVRADO, H. P., JUNQUEIRA, A. O. R., \& SILVA, S. H. G., 2005, Succession in rocky intertidal benthic communities in areas with different pollution levels at Guanabara bay (RJ-Brazil). Braz. Arch. Biol. Technol., 48: 951965. doi:10.1590/S1516-89132005000800012
BURTON, A. G., DELTON, L. D., HO, K. \& IRELAND, D. S., 2002, Sediment Toxicity Testing: Issues and Methods. In: D.J. Hoffman; B.A. Rattner; G.A. Burton; J. Cairns (eds) Handbook of ecotoxicology. $2^{\mathrm{a}}$ ed., 663p., Lewis Publishers, Boca Raton.

CAIRNS, J. JR., 1984, Multispecies toxicity testing. Environ. Toxicol. Chem. 3: 13. doi:10.1002/etc.5620030101

CAIRNS, J. JR., 1992, Paradigms flossed: the coming of age of environmental toxicology. Environ. Toxicol. Chem., 11:285-285. doi:10.1002/etc.5620110302

CAIRNS, J. JR., 2005, Ecotoxicology: an opportunity for the experimental sciences. Asian J. Exp. Sci., 19: 1-17.

CALOW, P., 1994, Ecotoxicology: what are we trying to protect? Environ. Toxicol. Chem., 13:1549. doi:10.1002/etc.5620131001

CALOW, P., 1998, Ecological Risk Assessment: Risk for What? How Do We Decide? Ecotox. Environ. Safe., 40:15-18. doi:10.1006/ eesa.1998.1636

CALOW, P. \& FORBES, V. E., 2003, Does ecotoxicology inform ecological risk assessment? Environ. Sci. Technol., 37: 147-151. doi:10.1021/es0324003

CAMARGO, M. M. P. \& MARTINEZ, C. B. R., 2006, Biochemical and physiological biomarkers in Prochilodus lineatus submitted to in situ tests in an urban stream in southern Brazil. Environ. Toxicol. Pharmacol., 21: 61-69. doi:10.1016/j.etap.2005.07.016

CARVALHO, S., LOMBARDI, J. V., PAIVA, M. J. T. R., FRANÇAMONKOLSKI, J. G. \& FERREIRA, J. R., 2006, Bioaccumulation of mercury in fish exposed to experimentally contaminated water and sediment. Bull. Environ. Contam. Toxicol., 77: 854-860. doi: 10.1007/s00128-006-1222-5

CESAR, A., ABESSA, D. M. S., PEREIRA, C. D. S., SANTOS, A. R., FERNÁNDEZ, N., CHOUERI, R. B. \& DELVALLS, T.A., 2009, A simple approach to integrate the ecotoxicological and chemical data for the establishment of environmental risk levels. Braz. Arch. Biol. Technol., 52: 233-240. doi:10.1590/S151689132009000100028

CHAPMAN, P. M., 1986, Sediment quality criteria from the Sediment Quality Triad: an example. Environ. Toxicol. Chem., 5: 957-964. doi:10.1002/etc.5620051104

CHAPMAN, P. M., 1989, Current approaches to developing sediment quality criteria. Environ. Toxicol. Chem., 8: 589-599. doi:10.1002/etc.5620080706

CHAPMAN, P. M., 1995a, Ecotoxicology and pollution - key issues. Mar. Pollut. Bull., 31: 167-177. doi:10.1016/0025326X(95)00101-R

CHAPMAN, P. M., 1995b, Extrapolating laboratory toxicity results to the field. Environ. Toxicol. Chem., 14: 927-930. doi:10.1002/ etc. 5620140601

CHAPMAN, P. M., 1998, New and emerging issues in ecotoxicology - the shape of testing to come? Aust. J. Ecotoxicol., 4:1-7.

CHAPMAN, P. M., 2002, Integrating toxicology and ecology: putting the "eco" into ecotoxicology. Mar. Pollut. Bull., 44: 7-15. doi:10.1016/S0025-326X(01)00253-3

CHAPMAN,P.M., 2006, Emerging substances-Emerging problems? Environ. Toxicol. Chem., 25: 1445-1447. doi:10.1897/06-025.1

CHAPMAN, P. M., 2008, Ecosystem services - assessment endpoints for scientific investigations. Mar. Pollut. Bull., 56: 1237-1238. doi:10.1016/j.marpolbul.2008.04.040

CHAPMAN, P. M. \& GUERRA, L. M., 2005, The "So What?" factor. Mar. Pollut. Bull., 50: 1457-1458. doi:10.1016/j. marpolbul.2005.10.010

CHAPMAN, P. M., WANG, F., ADAMS, W. J. \& GREEN, A., 1999, Appropriate Applications of Sediment Quality Values for Metals and Metalloids. Environ. Sci. Technol., 33: 3937-3941. doi:10.1021/es990083n

CHOUERI, R.B., CESAR, A., TORRES, R. J., ABESSA, D. M. S., MORAIS, R. D., PEREIRA, C. D. S., NASCIMENTO, M. 
R. L., MOZETO, A. A., RIBA, I. \& DELVALLS, T.A., 2009, Integrated sediment quality assessment in Paranaguá estuarine system, Southern Brazil. Ecotoxicol. Environ. Saf., 72: 18241831. doi:10.1016/j.ecoenv.2008.12.005

CLÉMENT, B., DEVAUX, A., PERRODIN, Y., DANJEAN, M. \& GHIDINI-FATUS, M., 2004, Assessment of sediment ecotoxicity and genotoxicity in freshwater laboratory microcosm. Ecotoxicology., 12: 323-333. doi:10.1023/ B:ECTX.0000033090.54897.94

CLEMENTS, W. H., 2000, Integrating effects of contaminants across levels of biological organization: an overview. J. Aquat. Ecosyst. Stress Recovery., 7:113-116. doi:10.1023/A:1009927612391

CLEMENTS, W.H. \& KIFFNEY,P. M., 1994, Assessing contaminant effects at higher levels of biological organization. Environ. Toxicol. Chem., 13: 357-359. doi:10.1002/etc.5620130301

CLEMENTS, W. H. \& NEWMAN, M. C., 2002, Community Ecotoxicology. John Wiley and Sons, Chichester, 336p.

CONAMA (CONSELHO NACIONAL DO MEIO AMBIENTE), 2005, Resolução CONAMA 357, 17 de março de 2005.

CONNEL, D., LAM, P., RICHARDSON, B., \& WU, R.., 1999, Introduction to ecotoxicology. Wiley-Blacwell, Oxford, 170p.

CORRÊA, A. X. R., TAMANAHA, M. S., HORITA, C. O., RADETSKI, M. R., CORRÊA, R. \& RADETSKI, C.M., 2009, Natural impacted freshwaters: in situ use of alginate immobilized algae to the assessment of algal response. Ecotoxicology., 18: 464-469. doi: 10.1007/s10646-009-0301-x

CRAPEZ, M. A. C., TOSTA, Z. T., BISPO, M. G. S. \& PEREIRA, D.C., 2000, Acute and chronic impacts caused by aromatic hydrocarbons on bacterial communities at Boa Viagem and Forte do Rio Branco beaches, Guanabara bay, Brazil. Environ. Pollut., 108: 291-295. doi:10.1016/S0269-7491(99)00186-4

DORNFELD, C. B., ESPÍNDOLA, E. L. G., FRACÁCIO, R., RODRIGUES, B.K., \& NOVELLI, A., 2006, Comparação de bioensaios laboratoriais e "in situ" utilizando Chironomus xanthus na avaliação da toxicidade de sedimentos do rio Monjolinho (São Carlos, SP). J. Braz. Soc. Ecotoxicol., 1: 161-165. doi:0.5132/ jbse.2006.02.014

DUTRA, B. K., FERNANDES, F. A. \& OLIVEIRA, G. T., 2008, Carbofuran-induced alterations in biochemical composition, lipoperoxidation, and $\mathrm{Na}+\mathrm{K}+\mathrm{ATPase}$ activity of Hyalella pleoacuta and Hyalella curvispina in bioassays. Comp. Biochem. Physiol., 147: 179-188. doi:10.1016/j.cbpc.2007.09.004

ECETOC (EUROPEAN CENTRE FOR ECOTOXICOLOGY AND TOXICOLOGY OF CHEMICALS), 2003, Aquatic Hazard Assessment II. ECETOC. Technical Report NN. 91, Brussels. $161 p$.

EMERY, V. L. JR., MOORE, D. W., GRAY, B. R., DUKE, M., GIBSON, A.B., WRIGHT, R. B. \& FARRAR, D., 1997, Development of a chronic sublethal sediment bioassay using the estuarine amphipod Leptocheirus plumulosus (shoemaker). Environ. Toxicol. Chem., 16: 1912-1920. doi:10.1002/ etc. 5620160921

EMLEN, J. M. \& SPRINGMAN, K. R., 2007, Developing Methods to Assess and Predict the Population Level Effects of Environmental Contaminants. Integr. Environ. Assess. Manag., 3:157-165. doi:10.1897/IEAM_2005-080.1

FLEEGER, J. W., CARMAN, K. R. \& NISBET, R. M., 2003, Indirect effects of contaminants in aquatic ecosystems. Sci. Total. Environ., 317: 207-233. doi:10.1016/S0048-9697(03)00141-4

FORBES, T. L., FORBES, V. E., GIESSING, A., HANSEN, R. \& KURE, L. K., 1998, Relative role of pore water versus ingested sediment in bioavailability of organic contaminants in marine sediments. Environ. Toxicol. Chem., 17: 2453-2462. doi: $10.1002 /$ etc. 5620171211
GLUSCZAK, L., MIRON, D. S., MORAES, B. S., SIMÕES, R. R., SCHETINGER, M. R. C., MORSCH, V. M. \& LORO, V. L., 2007, Acute effects of glyphosate herbicide on metabolic and enzymatic parameters of silver catfish (Rhamdia quelen). Comp. Biochem. Physiol., 146: 519-524. doi:10.1016/j. cbpc.2007.06.004

ISO (INTERNATIONAL ORGANIZATION FOR STANDARDIZATION), 2005, Water quality — Determination of the genotoxicity of water and waste water - Salmonella/ microsome test (Ames test) - 16240.

KREUTZ, L. C., BARCELLOS, L. J. G., SILVA, T. O., ANZILIERO, D., MARTINS, D., LORENSON, M., MARTENINGHE, A. \& SILVA, L. B., 2008, Acute toxicity test of agricultural pesticides on silver catfish (Rhamdia quelen) fingerlings. Cienc. Rural, 38: 1050-1055. doi:10.1590/S0103-84782008000400022

KUHN, T. S., 1970, A estrutura da revolução científica. $9^{\circ}$ ed, São Paulo: Perspectiva. 2006. Tradução:Beatriz Vianna Boeira e Nelson Boeira. Título original: The Structure of Scientific Revolutions.

KWOK, K. W. H., LEUNG, K. M. Y., LUI, G. S. G., CHU, V. K. H., LAM, P. K. S., MORRITT, D., MALTBY, L., BROCK, T. C. M., VAN DEN BRINK, P. J., WARNE, M. St J. \& CRANE, M., 2007, Comparison of Tropical and Temperate Freshwater Animal Species' Acute Sensitivities to Chemicals: Implications for Deriving Safe Extrapolation Factors. Integr. Environ. Assess. Manag., 3: 49-67. doi:10.1002/ieam.5630030105

LACHER, T. E. Jr. \& GOLDSTEIN, M. I., 1997, Tropical ecotoxicology: status and needs. Environ. Toxicol. Chem., 16: 100-111. doi:10.1002/etc.5620160111

LAM, P. K. S. \& GRAY, J. S., 2001, Predicting effects of toxic chemicals in the marine environment. Mar. Pollut. Bull., 42: 169-173. doi:10.1016/S0025-326X(00)00178-8

LANDIS, W. G., MATTHEWS, G. B., MATTHEWS, R. A., SERGEANT, A., 1994, Application of multivariate techniques to endpoint determination, selection and evaluation in ecological risk assessment. Environ. Toxicol. Chem., 13: 1917-1927. doi:10.1002/etc.5620131207

LANDIS, W. G. \& YU, M., 2003, Introduction to Environmental Toxicology: Impacts of Chemicals upon Ecological Systems. Lewis Publishers, Boca Raton, $3^{\mathrm{a} e d .,}$ 328p.

LATTUADA, R. M., MENEZES, C. T. B., PAVEI, P. T., PERALBA, M. C. R. \& SANTOS, J.H.Z., 2009, Determination of metals by total reflection X-ray fluorescence and evaluation of toxicity of a river impacted by coal mining in the south of Brazil. J. Hazard. Mater., 163: 531-537. doi:10.1016/j.jhazmat.2008.07.003

LIBER, K., GOODFELLOW, W., DEN BESTEN, P., CLEMENTS, W., GAllOWAY, T., GERHARDT, A., GREEN, A. \& SIMPSON, S., 2007, In Situ-Based Effects Measures: Considerations for Improving Methods and Approaches. Integr. Environ. Assess. Manage., 3: 246-258. doi:10.1897/2006029FIN.1

LOPES, I., MOREIRA-SANTOS, M., da SILVA, E. M., SOUSA, J. P., GUILHERMINO, L., SOARES, A. M. V. M. \& RIBEIRO, R., 2007, In situ assays with tropical cladocerans to evaluate edge-of-field pesticide runoff toxicity. Chemosphere., 67: 22502256. doi:10.1016/j.chemosphere.2006.12.009

LÜCHMANN, K. H., TOLEDO-SILVA, G., BAINY, A. F. C. D. \& MARQUES, M. R. F., 2007, Glutathione S-transferase cytosolic isoform in the pink-shrimp, Farfantepenaeus brasiliensis, from Conceição lagoon, Santa Catarina Island, SC, Brazil. Environ. Int., 33: 546-549. doi:10.1016/j.envint.2006.11.005

MACDONALD D. D. \& INGERSOLL C. G., 2003, A guidance manual to support the assessment of contaminated sediments in freshwater, estuarine and marine ecosystems in British 
Columbia. Volume VI: Supplemental Guidance on the Design and Implementation of Detailed Site Investigations in Marine and Estuarine Ecosystems. British Columbia Ministry of Water, Land, and Air Protection. Victoria. 63p.

MAGAlHÃES, D. P. \& FERRÃO FILHO, A. S., 2008, A ecotoxicologia como ferramenta no biomonitoramento de ecossistemas aquáticos. Oecol. Brasil., 12: 355-381. doi: 10.4257/oeco.2008.1203.03

MALTBY, L., 1999, Studying stress: the importance of organismlevel responses. Ecol. Appl., 9: 431-440. doi:10.1890/1051-0761

MARANHÃO, L. A., ABREU, I., SANTELLI, R., CORDEIRO, R.C., SOARES-GOMES, A., MOREIRAS, L. B., MORAIS, R. D. \& ABESSA, D. M. S., 2009, Sediment toxicity assessment of Guanabara Bay, Rio de Janeiro, Brazil. J. Coastal Res., 56: 851-855.

MAYER-PINTO, M. \& JUNQUEIRA, A.O.R., 2003, Effects of organic pollution on the initial development of fouling communities in a tropical bay, Brazil. Mar. Pollut. Bull., 46: 1495-1503. doi:10.1016/S0025-326X(03)00249-2

McGEE B. L., FISHER D. J., WRIGHT D. A., YONKOS L. T., ZIEGLER G. P., TURLEY, S. D., FARRAR, J. D., MOORE, D. W. \& BRIDGES T. S., 2004, A field test and comparison of acute and chronic sediment toxicity tests with the estuarine amphipod Leptocheirus plumulosus in Chesapeake bay, USA. Environ. Toxicol. Chem., 23: 1751-1761. doi: 10.1897/03-326

MCLUSKY, D. \& ELLIOTT, M., 2004, The estuarine ecosystem: ecology, threats and management. Oxford University Press, $3^{\text {a }}$ ed. $214 \mathrm{p}$.

McPHERSON, C. A. \& CHAPMAN, P. M., 2000, Copper Effects on Potential Sediment Test Organisms: the Importance of Appropriate Sensitivity. Mar. Pollut. Bull., 40: 656-665. doi:10.1016/S0025-326X(00)00043-6

MOISEENKO, T. I., 2008, Aquatic ecotoxicology: theoretical principles and practical application. Wat. Res., 35: 530-541. doi:10.1134/S0097807808050047

MØLLER, V., FORBES, V. \& DEPLEDGE, M., 1994, Influence of acclimation and exposure temperature on the acute toxicity of cadmium to the freshwater snail Potamopyrgus antipodarum (hydrobiidae). Environ. Toxicol. Chem., 13: 1519-1524. doi: 10.1002/etc.5620130914

NEWMAN, M. C. \& CLEMENTS, W. H., 2008, Ecotoxicology: A comprehensive treatment. Taylor \& Francis Boca Raton, New York, 852p.

NORTON, S. B., SCHALIE, W.H., SERGEANT, A., BLAKEHEDGES, L., WENTSEL, R., SERVEISS, V. B., MARCY, S. M., CIRONE, P. A., RODIER, D. J., ORR, R. L. \& WHARTON, S., 2002, Ecological Risk Assessment: U.S. EPA's Current Guidelines and Future Directions. In: D.J. Hoffman; B.A. Rattner; G.A. Burton; J. Cairns. Handbook of ecotoxicology. $2^{\mathrm{a}}$ ed., 663p., Lewis Publishers, Boca Raton.

OLIVEIRA, C. A., ARAÚJO, C. V. M., NASCIMENTO, R. B., STROTMANN, U. J. \& da SILVA, E.M., 2007, Utilisation of respirometry to assess organic matter reduction of effluents from the Camaçari Industrial Complex (BA, Brazil). Braz. Arch. Biol. Technol., 50: 311-319. doi:10.1590/S1516-89132007000200016

PONTASCH, K. W. \& CAIRNS, J. JR., 1991, Multispecies Toxicity Tests Using Indigenous Organisms: Predicting the Effects of Complex Effluents in Streams. Arch. Environ. Contam. Toxicol., 20: 103-112. doi:10.1007/BF01065335

PONTASCH, K. W., NIEDERLEHNER, B. R. \& CAIRNS, J. JR., 1989, Comparisons of single-species, microcosm and field responses to a complex effluent. Environ. Toxicol. Chem., 8: 521-532. doi:10.1002/etc.5620080609

RELYEA, R. A., 2009, A cocktail of contaminants: how mixtures of pesticides at low concentrations affect aquatic communities. Oecologia, 159: 363-376. doi:10.1007/s00442-008-1213-9

RELYEA, R. A. \& HOVERMAN, J., 2006, Assessing the ecology in ecotoxicology: a review and synthesis in freshwater systems. Ecol. Lett., 9: 1157-1171. doi:10.1111/j.1461-0248.2006.00966.x

RESGALLA, C. JR., NOLDIN, J. A., TAMANAHA, M. S., DESCHAMPS, F. C., EBERHARDT, D. S. \& RORIG, L. R., 2007, Risk analysis of herbicide quinclorac residues in irrigated rice areas, Santa Catarina, Brazil. Ecotoxicology., 16: 565-571. doi:10.1007/s10646-007-0165-x

ROACH, A. C., JONES, A. R. \& MURRAY, A., 2001, Using benthic recruitment to assess the significance of contaminated sediments: the influence of taxonomic resolution. Environ. Pollut.,112: 131143. doi:10.1016/S0269-7491(00)00124-X

RODGHER, S., ESPÍNDOLA, E. L. G., ROCHA, O., FRACÁCIO, R., PEREIRA, R. H. G. \& RODRIGUES M. H. S., 2005, Limnological and ecotoxicological studies in the cascade of reservoirs in the Tietê river (São Paulo, Brazil). Braz. J. Biol.65: 697-710. doi:10.1590/S1519-69842005000400017

SCHMITT-JANSEN, M., VEIT,U.,DUDEL, G. \& ALTENBURGER, R., 2008, An ecological perspective in aquatic ecotoxicology: Approaches and challenges. Basic Appl. Ecol., 9: 337-345. doi:10.1016/j.baae.2007.08.008

SIMPSON, S. L. \& BATLEY, G. E., 2007, Predicting Metal Toxicity in Sediments: A Critique of Current Approaches. Integr. Environ. Assess. Manage., 3: 18-31. doi: 10.1002/ieam.5630030103

SOARES, A. M. V. M. \& CALOW, P., 1993, Seeking standardization in ecotoxicology. In: SOARES, A. M. V. M. \& CALOW, P. (Eds.), Progress in standardization of aquatic toxicity test., Boca Raton, Lewis Publishers.

UNDERWOOD, A. J. \& PETERSON, C. H., 1988, Towards an ecological framework for investigating pollution. Mar. Ecol., 46: 227-234.

USEPA (UNITED STATES ENVIRONMENTAL PROTECTION AGENCY), 1998, Guidelines for Ecological Risk Assessment. U.S. Environmental Protection Agency, Risk Assessment Forum, Washington, DC, EPA/630/R095/002F.

WATZIN, M. C., ROSCIGNO, P. F. \& BURKE, W. D., 1994, Community-level field method for testing the toxicity of contaminated sediments in estuaries. Environ. Toxicol. Chem., 13: 1187-1193. doi:10.1002/etc.5620130720 